\title{
PEMANFAATAN KEMBALI AIR LIMBAH TEROLAH DENGAN SISTEM WETLAND UNTUK PEMBUATAN KULIT GLACE
}

\section{UTILIZATION OF WASTEWATER TREATED BY THE WETLAND SYSTEM FOR MAKING GLACE LEATHER}

\author{
Sri Sutyasmi \\ Balai Besar Kulit, Karet, dan Plastik, Yogyakarta \\ E-mail: srisutyasmi@ymail.com
}

Diterima: 4 Maret 2014 Direvisi: 8 Mei 2014 Disetujui: 12 Mei 2014

\begin{abstract}
Tanneries use large quantities of water and produce high pollutant load. Wastewater recycling is an effective way to conserve water supplies. The purpose of this study was to reuse wastewater that has been treated with a wetland system to save water and to apply cleaner production in tannery industry. The treated wastewater was tested in accordance with the test requirements of water used for leather tanning process. The treated wastewater test results met the requirements of SNI 060649-1989 Water for the tanning process. Furthermore, treated wastewater was used for leather tanning process with variations of wastewater used were 0, 25, 50, 75 and 100\%. The resulting leather was tested in accordance with SNI 06-0253-1989 Quality requirement of goat glace leather. The test results met the SNI. Utilization of $75 \%$ wastewater gave the best result.
\end{abstract}

Keyword: glace leather, reuse, tannery, wastewater, wetland

\begin{abstract}
ABSTRAK
Penggunaan air di industri penyamakan kulit sangat besar, demikian juga air limbah yang dihasilkan, yang tentu saja mengandung beban pencemar yang tinggi sehingga perlu pengolahan yang sesuai agar bisa digunakan kembali untuk menghemat sumber daya air. Tujuan penelitian ini adalah memanfaatkan kembali air limbah yang sudah terolah dengan sistem wetland untuk menghemat air dan menerapan produksi bersih di industri penyamakan kulit. Air limbah yang sudah terolah diuji sesuai dengan persyaratan uji air yang digunakan untuk proses penyamakan kulit. Hasil uji air limbah terolah memenuhi persyaratan SNI 06-0649-1989 Air untuk proses penyamakan kulit. Selanjutnya air limbah terolah digunakan untuk proses penyamakan kulit dengan variasi air limbah yang digunakan adalah $0,25,50,75$, dan $100 \%$. Kulit tersamak yang dihasilkan diuji sesuai dengan SNI 06-0253-1989 tentang Syarat Mutu Kulit Glace Kambing. Hasil uji kulit memenuhi SNI dan hasil uji mutu kulit terbaik adalah pada variasi $75 \%$ penggunaan air limbah.
\end{abstract}

Kata kunci: kulit glace, penggunaan kembali, penyamakan kulit, air limbah, wetland

\section{PENDAHULUAN}

Perkembangan sektor industri khususnya industri penyamakan kulit berkembang cukup pesat. Seiring dengan itu, penggunaan/ pemanfaatan sumber daya alam khususnya air menjadi meningkat pula, mengingat industri penyamakan kulit memerlukan air yang cukup besar $\left( \pm 45 \mathrm{~m}^{3}\right)$ per ton kulit mentah yang di- proses, sehingga air limbah yang dihasilkan juga cukup besar, yaitu hampir sama dengan penggunaan air (Rao et al. 2013), dan air limbah tersebut tidak dapat digunakan lagi tanpa pengolahan terlebih dahulu. Menurut Krishanamoorthi (2009), jumlah air limbah yang dihasilkan oleh industri penyamakan kulit bervariasi antara 30-50 liter untuk setiap 
kilogram kulit yang diproses.

Mengingat limbah cair yang dihasilkan oleh industri penyamakan kulit cukup banyak, maka perlu pengolahan agar tidak menyebabkan pencemaran. Menurut Tünay et al. (2013), untuk mengantisipasi potensi dampak tersebut, maka perlu upaya minimasi limbah melalui berbagai alternatif teknologi pengolahan limbah yang efektif dan efisien, salah satu alternatifnya adalah menggunakan sistem lahan basah buatan (constructed wetlands).

Upaya preventif atau pencegahan yang perlu dikembangkan yaitu dengan menerapkan sistem produksi bersih (cleaner production), yaitu suatu langkah preventif dan kuratif untuk mengurangi produksi limbah dan pencemaran lingkungan. Upaya ini difokuskan pada alur proses produksi dari mulai penanganan bahan baku hingga pemasaran produk dan penanganan limbah. Penekanan aktifitas dititikberatkan pada sumber kegiatan proses produksi yang menghasilkan limbah (Li et al., 2010).

Pengolahan lanjutan dengan constructed wetland merupakan pengolahan alternatif yang memungkinkan bahwa air limbah hasil olahannya dapat digunakan kembali untuk proses penyamakan kulit. Beberapa keunggulan wetland dibandingkan dengan teknologi pengolah air limbah konvensional lainnya antara lain murah dalam biaya operasi-rawatnya, toleran terhadap berbagai tingkat konsentrasi pencemar, mampu mereduksi logam berat, tanamannya dapat dimanfaatkan untuk pakan ternak, kertas, pupuk, tanaman hias, mendukung fungsi ekologis, kawasan hijau, habitat satwa, dan kawasan rekreasi (Munawar et al., 2011; Hidayah dan Aditya, 2010).

Aktivitas pengolahan unsur hara yang diambil dari air limbah inilah yang "dimasak" di zat hijau daun (klorofil) sehingga tanaman menjadi tumbuh, baik fisiknya maupun jumlah tunasnya, sekaligus mengurangi polutan di dalam air limbah (Truu, et al., 2009). Proses pengolahan air limbah dengan teknologi constructed wetland dapat terjadi melalui proses kimia, fisika, dan biologis yang merupakan interaksi antara mikroorganisme (Hidayah dan Aditya, 2010; Suharto et al., 2012).

Prasety (2011) menyatakan bahwa rawa buatan (constructed wetland) dapat diklasifikasikan menjadi dua jenis, yaitu rawa buatan yang air limbahnya mengalir di permukaan (free water surface system) dan rawa buatan yang air limbahnya mengalir di bawah permukaan rawa (subsurface flow system). Pada subsurface flow system (SSF), pengolahan terjadi ketika air limbah mengalir secara perlahan melalui tanaman yang ditanam pada media berpori, misalnya batu pecah, kerikil dan tanah yang berbeda (Vymazal, 2009).

Besarnya konsumsi air di industri penyamakan kulit mengakibatkan pembengkakan biaya pada penggunaan air. Hal ini bisa dikurangi dengan menggunakan kembali air limbah dan bahan kimia yang sudah terolah untuk proses penyamakan kulit (Seggiani et al., 2013; Scholz and Lucas, 2013).

Air digunakan mulai dari proses pencucian, perendaman sampai dengan proses pengecatan dasar/peminyakan (fatliquoring), bahkan untuk jenis cat tertentu sampai dengan pengecatan akhir/tutup. Air untuk penyamakan kulit tidak boleh mengandung zat-zat yang dapat bereaksi dengan bahan-bahan yang digunakan dalam proses penyamakan kulit karena akan mempengaruhi proses penyamakan tersebut. Air yang digunakan untuk penyamakan harus jernih dan tidak mengandung mikroorganisme, serta bebas dari garam-garam besi dan kesadahan (Pfister et al., 2011).

Persyaratan air untuk penyamakan terdapat pada SNI-06-0649-1989 sebagai berikut: kesadahan jumlah maksimum 12 Derajat Jerman, $\mathrm{Fe}$ maksimum $6 \mathrm{mg} / \mathrm{l}, \mathrm{NaCl}$ maksimum $100 \mathrm{mg} / \mathrm{l}$, bilangan $\mathrm{KMnO}_{4}$ maksimum $5 \mathrm{mg} / \mathrm{l}$, kekeruhan maksimum $50 \mathrm{mg} / \mathrm{l}, \mathrm{pH}$ minimum 6 dan maksimum 7,5.

Pawiroharsono (2011), menyatakan bahwa proses awal dari penyamakan kulit terdiri dari proses perendaman yaitu untuk mengembalikan kadar air, membersihkan kotoran, darah, dan garam yang masih melekat pada kulit. Selanjutnya proses pengapuran untuk membengkakkan kulit, melepas sisa daging dari kulit, menyabunkan lemak pada kulit. pembuangan kapur untuk menghilangkan sisa kapur dalam kulit, menetralkan kulit, menghindari pengkerutan kulit dan menghindari timbulnya endapan kapur. Kemudian dilanjutkan dengan pengikisan protein dan pengasaman untuk memberikan suasa- 
na asam pada kulit sehingga lebih sesuai dengan senyawa penyamak dan kulit dan lebih tahan terhadap serangga bakteri pembusuk.

Kulit yang telah tersamak terbentuk dari reaksi antara serat kalogen di dalam kulit hewan dan zat penyamak (tannin) yang biasanya menggunakan bahan penyamak, krom, bahan penyamak tawas atau bahan penyamak lain seperti bahan penyamak nabati, bahan penyamak alum dan lain sebagainya (Dettmer et al. 2011).

Tujuan dari penelitian ini adalah memanfaatkan kembali air limbah yang sudah terolah dengan sistem wetland untuk menghemat air yang digunakan untuk proses penyamakan kulit dan menerapkan produksi bersih di industri penyamakan kulit.

\section{MATERI DAN METODE Bahan Penelitian}

Bahan yang digunakan dalam penelitian ini adalah kulit kambing, air limbah yang keluar dari wetland, bahan kimia untuk proses penyamakan kulit glace, dan kertas $\mathrm{pH}$.

\section{Peralatan Penelitian}

Peralatan penelitian terdiri atas rangkaian IPAL dari industri penyamakan kulit yang sudah dilengkapi dengan pengolahan wetland, drum penyamakan, timbangan, dan alat bantu lainnya.

\section{Metode Penelitian}

Pengolahan air limbah dalam penelitian ini didahului dengan pengolahan primer (koagulasi dan flokulasi), dilanjutkan dengan pengolahan sekunder (pengolahan biologi dengan sistem aerasi) dan terakhir adalah pengolahan tersier/ lanjutan dengan menggunakan sistem wetland. Air limbah terolah yang keluar dari wetland diuji dengan parameter uji sesuai dengan SNI 060649-1989 yaitu tentang air untuk penyamakan kulit. Selanjutnya, air limbah terolah tersebut digunakan untuk menyamak kulit glace dengan variasi penggunaan air limbah terolah adalah 0 , 25 , 50, 75, dan $100 \%$. Kulit tersamak kemudian diuji mutunya sesuai dengan SNI 06-0253-1989 yaitu tentang Syarat Mutu Kulit Glace Kambing, sehingga mutu kulit dapat diketahui.

\section{HASIL DAN PEMBAHASAN}

Hasil uji mutu air limbah terolah dengan sistem wetland yang akan digunakan untuk menyamak kulit adalah seperti Tabel 1. Dari data tersebut dapat diketahui bahwa seluruh parameter uji untuk air limbah terolah yang akan digunakan untuk menyamak kulit adalah memenuhi persyaratan untuk air yang digunakan menyamak kulit, kecuali kekeruhan yang sedikit diatas persyaratan yang di tentukan. Hal ini diduga karena masih banyak pasir yang terikut dalam aliran air limbah yang sebelumnya debit yang digunakan adalah besar (50 $\mathrm{ml} / \mathrm{menit})$, sedangkan debit yang dipakai (yang menghasilkan waktu tinggal yang cukup dalam wetland selama 4 hari) adalah $15 \mathrm{ml} /$ menit. Menurut Munazah (2008), waktu tinggal 5 hari di wetland, penurunan COD $86,52 \%$, sedangkan dalam penelitian ini penurunan BOD

Tabel 1. Hasil uji air limbah terolah dengan wetland untuk penyamakan kulit dan persyaratannya

\begin{tabular}{lccc}
\hline Parameter & $\begin{array}{c}\text { Hasil uji air limbah terolah dari salah satu } \\
\text { industri kulit di Yogyakarta }\end{array}$ & \multicolumn{2}{c}{ Persyaratan } \\
\cline { 3 - 4 } & 0,0488 & - & 12,0 \\
\hline Kesadahan jumlah & & & \\
(Derajat Jerman) & 2,6704 & - & 50,0 \\
Kadar besi (mg/l) & 0,2980 & - & 100,0 \\
$\mathrm{NaCl}(\mathrm{mg} / \mathrm{l})$ & 4,8 & - & 5,0 \\
Bilangan Permanganat/ & & & \\
$\mathrm{KmnO}_{4}(\mathrm{mg} / \mathrm{l})$ & 69,2 & - & 50,0 \\
$\mathrm{Kekeruhan}(\mathrm{mg} / \mathrm{l})_{\mathrm{pH}}$ & 7,5 & 6 & 7,5 \\
\hline
\end{tabular}


dan COD adalah $98,34 \%$ dan $67,96 \%$. Selain itu, kemungkinan kekeruhan disebabkan oleh bahan organik yang masih ada dalam air limbah tersebut. Hal ini dibuktikan dengan pemeriksaan kandungan pencemar pada air limbah terolah tersebut. Hasil uji BOD, COD, dan TSS dari air limbah terolah yang keluar dari wetland terlihat pada Tabel 2. Dari data tersebut dapat diketahui bahwa nilai COD adalah paling tinggi dibanding parameter yang lain. Inilah salah satu kemungkinan yang menyebabkan kekeruhan pada air limbah terolah yang keluar dari wetland tidak memenuhi persyaratan untuk air yang digunakan untuk proses penyamakan kulit.

Menurut Pfester (2011), air yang digunakan dalam proses penyamakan kulit harus jernih dan tidak mengandung mikroorganisme, serta bebas dari garam-garam besi dan kesadahan. Hal tersebut tercermin pada hasil uji kualitas air yang digunakan untuk proses penyamakan kulit yang hampir semua memenuhi persyaratan air untuk proses penyamakan kulit.

Kulit glace adalah kulit kambing yang disamak krom dan di finish, biasanya digunakan untuk atasan sepatu wanita. (BSN, 1989b). Protein kolagen sangat menentukan mutu kulit samak, semakin dewasa umur ternak semakin tinggi pula kandungan kolagennya. Elastin adalah protein serabut berwarna kuning. Protein ini mempunyai peran yang besar terhadap kemuluran kulit samak, sedangkan protein kolagen sangat berperan dalam menentukan kekuatan kulit (Triatmojo, 2009).

Kulit kambing yang disamak dengan air limbah terolah disajikan dalam Gambar 1. Pemberian warna terang (biru) untuk mengetahui ada tidaknya pengaruh penggunaan air limbah terolah terhadap warna kulit. Gambar 1 menunjukkan bahwa kulit yang diberi warna terang tetap terang (tidak terpengaruh penggunaan air limbah terolah) walaupun

Tabel 2. Hasil uji COD, BOD dan TSS dari air limbah yang keluar dari wetland

\begin{tabular}{cc}
\hline Parameter & Hasil uji \\
\hline BOD $(\mathrm{mg} / \mathrm{l})$ & 10,32 \\
COD $(\mathrm{mg} / \mathrm{l})$ & 409 \\
TSS $(\mathrm{mg} / \mathrm{l})$ & 145 \\
\hline
\end{tabular}

kekeruhan air limbah terolah tersebut tidak memenuhi persyaratan. Hal ini menunjukkan bahwa air limbah terolah yang keluar dari wetland dalam penelitian ini dapat digunakan kembali untuk proses penyamakan kulit.

Untuk mengetahui mutu kulit secara organoleptis, fisika, dan kimia maka hasil uji mutu kulit dapat ditihat pada Tabel 3. Dari hasil uji organoleptis dapat diketahui bahwa semua uji organoleptis dari kulit hasil penelitian memenuhi syarat mutu kulit glace kambing (BSN, 1989), kecuali kekuatan sobek pada kode I dan II yaitu pemakaian air limbah $25 \%$ dan 50\%. Hal ini kemungkinan disebabkan karena mutu kulit mentahnya yang kurang baik, sehingga mempengaruhi mutu kulit jadinya.

Hasil uji fisika kulit glace dapat dilihat pada Tabel 4. Dari data hasil uji fisika menunjukkan bahwa tebal, penyamakan, ketahanan zwick, dan kekuatan tarik semuanya memenuhi SNI 060253-1989. Hal ini kemungkinan karena ternak yang dipotong sudah dewasasehingga kandungan protein kolagennya tinggi. Kandungan kolagen dalam kulit sangat menentukan kualitas kulit (Triatmojo, 2009).

Hasil uji kemuluran kulit yang diproses dengan air limbah terolah variasi $50 \%$ dan $100 \%$ adalah sedikit melebihi SNI 06-0253-1989, karena dalam SNI tersebut kemuluran maksimal adalah 55\%. Hal ini diduga karena kemuluran kulit ini sangat tergantung pada elastin (protein serabut berwarna kuning) dimana kemuluran

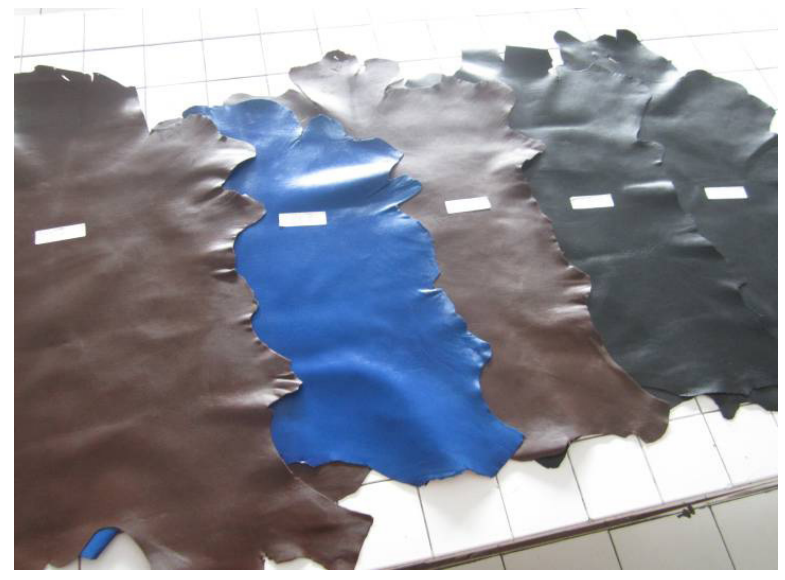

Gambar 1. Kulit glace hasil penelitian, berturutturut dari kiri adalah kontrol (penyamakan dengan air bersih, 25\% air limbah, 50\% air limbah, 75\% air limbah dan 100\% air limbah) 
Tabel 3. Mutu kulit glace kambing secara organoleptis.

\begin{tabular}{|c|c|c|c|c|c|c|}
\hline \multirow[t]{2}{*}{ Macam uji/kode } & \multicolumn{5}{|c|}{ Hasil uji } & \multirow{2}{*}{$\begin{array}{c}\text { Persyaratan } \\
\text { SNI 06-0253-1989 }\end{array}$} \\
\hline & K & I & II & III & IV & \\
\hline Kerusakan (\%) & 9,91 & 8,70 & 8,70 & 8,70 & 8,33 & Kurang dari 40 \\
\hline Kondisi kulit & $\begin{array}{l}\text { Tidak } \\
\text { gembos }\end{array}$ & $\begin{array}{l}\text { Tidak } \\
\text { gembos }\end{array}$ & $\begin{array}{l}\text { Tidak } \\
\text { gembos }\end{array}$ & $\begin{array}{l}\text { Tidak } \\
\text { gembos }\end{array}$ & $\begin{array}{l}\text { Tidak } \\
\text { gembos }\end{array}$ & Tidak gembos \\
\hline Kekuatan sobek & Tinggi & $\begin{array}{l}\text { Cukup } \\
\text { Tinggi }\end{array}$ & $\begin{array}{l}\text { Cukup } \\
\text { Tinggi }\end{array}$ & Tinggi & Tinggi & Tinggi \\
\hline Kelentingan & Lenting & Lenting & Lenting & Lenting & Lenting & Lenting \\
\hline \multicolumn{7}{|l|}{$\begin{array}{l}\text { Ketahanan gosok } \\
\text { cat }\end{array}$} \\
\hline a. Basah & $\begin{array}{c}4 / 5 \text {, tidak } \\
\text { luntur }\end{array}$ & $\begin{array}{l}5 \text {, tidak } \\
\text { luntur }\end{array}$ & $\begin{array}{l}5 \text {, tidak } \\
\text { luntur }\end{array}$ & $\begin{array}{l}4 / 5 \text {, tidak } \\
\text { luntur }\end{array}$ & $\begin{array}{l}5 \text {, tidak } \\
\text { luntur }\end{array}$ & Sedikit luntur \\
\hline b. Kering & $\begin{array}{l}5, \text { tidak } \\
\text { luntur }\end{array}$ & $\begin{array}{l}5 \text {, tidak } \\
\text { luntur }\end{array}$ & $\begin{array}{l}5 \text {, tidak } \\
\text { luntur }\end{array}$ & $\begin{array}{l}5, \text { tidak } \\
\text { luntur }\end{array}$ & $\begin{array}{l}5 \text {, tidak } \\
\text { luntur }\end{array}$ & tidak luntur \\
\hline
\end{tabular}

Keterangan: (K) kontrol (air bersih $100 \%$ ); (I) air limbah 25\% + air bersih 75\%; (II) air limbah 50\% + air bersih 50\%; (III) air limbah 75\% + air bersih 25\%; (IV) air limbah $100 \%$

Tabel 4. Hasil uji fisika kulit glace kambing.

\begin{tabular}{|c|c|c|c|c|c|c|}
\hline \multirow[t]{2}{*}{ Macam uji } & \multicolumn{5}{|c|}{ Hasil uji } & \multirow{2}{*}{$\begin{array}{c}\text { Persyaratan } \\
\text { SNI 06-0253-1989 }\end{array}$} \\
\hline & $\mathrm{K}$ & I & II & III & IV & \\
\hline Tebal (mm) & 0,70 & 0,80 & 0,74 & 0,80 & 0,80 & Min 0,6 \\
\hline Penyamakan & $\begin{array}{c}\text { Masak } \\
\text { (susut 0\%) }\end{array}$ & $\begin{array}{c}\text { Masak } \\
\text { (susut } 0 \% \text { ) }\end{array}$ & $\begin{array}{c}\text { Masak } \\
\text { (susut 0\%) }\end{array}$ & $\begin{array}{c}\text { Masak } \\
\text { (susut 0\%) }\end{array}$ & $\begin{array}{c}\text { Masak } \\
\text { (susut 0\%) }\end{array}$ & $\begin{array}{c}\text { Masak, } \\
\text { maksimum 10\% }\end{array}$ \\
\hline $\begin{array}{l}\text { Ketahanan } \\
\text { Zwik }\end{array}$ & $\begin{array}{l}\text { Nerf dan cat } \\
\text { tidak retak } \\
(7,39 \mathrm{~mm})\end{array}$ & $\begin{array}{l}\text { Nerf dan cat } \\
\text { tidak retak } \\
(7,27 \mathrm{~mm})\end{array}$ & $\begin{array}{l}\text { Nerf dan cat } \\
\text { tidak retak } \\
(7,54 \mathrm{~mm})\end{array}$ & $\begin{array}{l}\text { Nerf dan cat } \\
\text { tidak retak } \\
(8,23 \mathrm{~mm})\end{array}$ & $\begin{array}{l}\text { Nerf dan cat } \\
\text { tidak retak } \\
(7,82 \mathrm{~mm})\end{array}$ & nerf tidak pecah \\
\hline $\begin{array}{l}\text { Kekuatan } \\
\text { tarik, } \mathrm{kg} / \mathrm{cm}^{2}\end{array}$ & 319,41 & 188,75 & 124,59 & 279,56 & 213,79 & minimum 150 \\
\hline $\begin{array}{l}\text { Kemuluran, } \\
\%\end{array}$ & 42,96 & 41,01 & 57,71 & 47,44 & 58,86 & Maksimum 55 \\
\hline
\end{tabular}

Keterangan: (K) kontrol (air bersih $100 \%$ ); (I) air limbah 25\% + air bersih 75\%; (II) air limbah 50\% + air bersih 50\%; (III) air limbah 75\% + air bersih 25\%; (IV) air limbah $100 \%$

selalu berbanding terbalik dengan kekuatan tarik. Mutu terbaik pada uji fisika dari kulit hasil penelitian adalah variasi $75 \%$.

Hasil uji kimia terlihat pada Tabel 5. Dari hasil uji kimia dapat diketahui bahwa kadar air dari kulit hasil penelitian semua memenuhi SNI 06-0253-1989 (maksimal 18\%), sedangkan untuk kadar abu jumlah, semua variasi tidak memenuhi SNI 06-0253-1989 (maksimal 2\% diatas kadar $\mathrm{Cr}_{2} \mathrm{O}_{3}$ ). Hal ini diduga karena pada waktu proses pencucian baik tanning maupun pada beamhouse kurang bersih sehingga menambah kadar abu jumlah. Hasil uji kadar $\mathrm{Cr}_{2} \mathrm{O}_{3}$ dari semua variasi memenuhi SNI 060253-1989 (minimum 2,5\%). Kadar lemak/ minyak dari kulit hasil penelitian ini yang memenuhi SNI 06-0253-1989 adalah kode I (variasi 25\% pemakaian air limbah terolah) dan kode IV (variasi 100\% pemakaian air limbah terolah), sedangkan variasi lainnya termasuk kontrol (kode K) tidak memenuhi SNI 060253-1989. Hal ini diduga karena dalam proses penyamakannya terlalu banyak minyak yang digunakan. Sedangkan $\mathrm{pH}$ kulit hasil penelitian 
Tabel 5. Hasil Uji kimia kulit glace kambing

\begin{tabular}{lcccccc}
\hline $\begin{array}{l}\text { Macam uji/ } \\
\text { kode }\end{array}$ & \multicolumn{5}{c}{ Hasil uji } & Persyaratan \\
\cline { 2 - 6 } & $\mathrm{K}$ & $\mathrm{I}$ & $\mathrm{II}$ & $\mathrm{III}$ & $\mathrm{IV}$ & SNI 06-0253-1989 \\
\hline $\begin{array}{l}\text { Kadar air, } \\
\text { \% }\end{array}$ & 16 & 17,98 & 17,00 & 18,00 & 16,99 & Maksimum 18 \\
$\begin{array}{l}\text { Kadar abu } \\
\text { jumlah, \% }\end{array}$ & $\begin{array}{c}4,90 \mathrm{di} \\
\text { atas kadar } \\
\mathrm{Cr}_{2} \mathrm{O}_{3}\end{array}$ & $\begin{array}{c}5,81 \mathrm{di} \\
\text { atas kadar } \\
\mathrm{Cr}_{2} \mathrm{O}_{3}\end{array}$ & $\begin{array}{c}5,45 \mathrm{di} \\
\text { atas kadar } \\
\mathrm{Cr}_{2} \mathrm{O}_{3}\end{array}$ & $\begin{array}{c}5,33 \mathrm{di} \\
\text { atas kadar } \\
\mathrm{Cr}_{2} \mathrm{O}_{3}\end{array}$ & $\begin{array}{c}4,58 \mathrm{di} \\
\text { atas kadar } \\
\mathrm{Cr}_{2} \mathrm{O}_{3}\end{array}$ & $\begin{array}{c}\text { maks 2 \% diatas } \\
\text { kadar } \mathrm{Cr}_{2} \mathrm{O}_{3}\end{array}$ \\
$\begin{array}{l}\text { Kadar } \\
\text { Cr } \mathrm{O}_{3} \%\end{array}$ & 3,56 & 4,16 & 5,05 & 4,38 & 4,58 & Minimum 2,5 \\
$\begin{array}{l}\text { Kadar } \\
\text { lemak, \% }\end{array}$ & 9,86 & 6,34 & 9,38 & 8,46 & 7,00 & $4-8$ \\
pH & 6,48 & 6,36 & 6,20 & 6,44 & 6,34 & $3,5-7$ \\
\hline
\end{tabular}

Keterangan: (K) kontrol (air bersih $100 \%$ ); (I) air limbah 25\% + air bersih 75\%; (II) air limbah 50\% + air bersih 50\%; (III) air limbah 75\% + air bersih 25\%; (IV) air limbah $100 \%$

ini semua hampir sama yaitu sekitar 6 lebih dan semuanya memenuhi SNI 06-0253-1989 yaitu antara 3,5-7.

\section{KESIMPULAN DAN SARAN \\ Kesimpulan}

Air limbah terolah dengan sistem wetland dapat memenuhi persyaratan air untuk proses penyamakan kulit sehingga dapat digunakan kembali untuk proses penyamakan kulit glace sehingga industri kulit dapat menerapkan produksi bersih dan menghemat sumber daya air. Penggunaan air limbah terolah yang terbaik adalah variasi $75 \%$ dan pemakaian air limbah terolah tidak mempengaruhi mutu maupun warna dari kulit glace.

\section{Saran}

Disarankan untuk di terapkan di industri kulit berskala menengah/besar dan penelitian selanjutnya harus diperhitungkan waktu tinggal cukup di bak wetland.

\section{UCAPAN TERIMA KASIH}

Pada kesempatan ini kami mengucapkan terimakasih kepada bapak Heru Budi Susanto, Widodo, dan Wahono serta seluruh tim yang telah banyak membantu sampai selesainya penelitian ini.

\section{DAFTAR PUSTAKA}

BSN (Badan Standardisasi nasional), 1989a. SNI 06-0649-1989 Air untuk Proses Penyamakan Kulit Samak Nabati.

BSN (Badan Standardisasi nasional), 1989b. SNI 06-0253-1989 Syarat Mutu Kulit Glace Kambing.

Dettmer, A., Ayub, M. A., and Gutterres, M., 2011. Hide unhairing and characterization of commercial enzymes used in leather manufacture, Brazilian Journal of Chemical Engineering, 28(3): 373-380.

Hidayah, E.N. dan Aditya, W., 2010. Potensi dan pengaruh tanaman pada pengolahan air limbah domestik dengan sistem constructed wetland, Envirotek: Jurnal Ilmiah Teknik Lingkungan, 2(2): 11-18.

Krishanamoorthi, S, V., Sivakumar, K., Saravanan, T. V., and Prabhu, S., 2009., Treatment and reuse of tannery waste water by embedded system, Modern Applied Science, 3(1): 129-134.

Li, S., Li, J., Yi, J., and Shan, Z., 2010. Cleaner beam house processes trial on cattle sofa leather, Journal of Cleaner Production, 18(5): 471-477.

Munawar, A., Leitu, F. O., and Bustamam,H., 2011. Aquatic Plants for Acid Mine Drainage Remediation in Simulated 
Wetland Systems, Jurnal Natur Indonesia, 13(3): 244-249.

Pawiroharsono, S., 2011. Penerapan enzim untuk penyamakan kulit ramah lingkungan, Jurnal Teknologi Lingkungan, 9(1): 51-58.

Pfister, S., Bayer, P., Koehler, A., and Hellweg, S., 2011. Environmental impacts of water use in global crop production: hotspots and trade-offs with land use, Environmental Science and Technology, 45(13): 57615768.

Prasety, I. A., 2011. Pengaruh Sub Surface constructed Wetland terhadap BOD, TSS dan $\mathrm{pH}$ pada Instalasi Pengolahan Air Limbah Domestic, Desertasi, Universitas Gadjah Mada.

Rao, R. J., Chandrababu, N. K., Muralidharan, C., Nair, B. U., Rao, P. G., and Ramasami, T., 2013. Recouping the wastewater: A way forward for cleaner leather processing, Journal of Cleaner Production, 11(5): 591599.

Scholz, W. and Lucas, M., 2013. Technoeconomic evaluation of membrane filtration for the recovery and re-use of tanning chemicals, Water Research, 37(8): 18591867.

Seggiani, M., Puccini, M., Castiello, D., Andrianini, D., Berni, P., and Vitolo, S., 2013. Municipal wastewater reclamation and reuse in the leather industry, Desalination and Water Treatment, 52: 1647-1653.
Suharto, B., Susanawati, L. D., dan Wilistien, B. I., 2011. Penurunan kandungan logam $\mathrm{pb}$ dan cr leachate melalui fitoremediasi bambu air (Equisetum hyemale) dan zeolit, Agrointek, 5(2): 133-143.

Triatmojo, S 2009, Implementasi produksi bersih dalam Industri penyamakan kulit guna Peningkatan efisiensi dan Pencegahan Pencemaran lingkungan, Pidato Pengukuhan Jabatan Guru Besar, Universitas Gadjah Mada.

Truu, M., Juhanson, J., and Truu, J., 2009. Microbial biomass, activity, and community composition in constructed wetlands, Science of the Total Environment, 407: 3958-3971.

Tünay, O., Kabdaşli, I., Orhon, D., and Cansever, G., 2010. Use and minimization of water in leather tanning processes, Water Science and Technology, 40(1): 237-244.

Vymazal, J., 2009. The use constructed wetlands with horizontal subsurface flow for various types of wastewater, Ecological Engineering, 35: 1-17. 
